\title{
POTENSI DAN KENDALA PENGEMBANGAN BUDIDAYA UDANG VANAMEI DI SULAWESI SELATAN
}

\author{
Abdul Mansyur ${ }^{*}$ dan Nur Ansari Rangka*) \\ *) Balai Riset Perikanan Budidaya Air Payau, Maros
}

\begin{abstract}
ABSTRAK
Udang vanamei merupakan udang introduksi yang masuk ke Indonesia pada tahun 2001 dan diresmikan pada tahun 2002 oleh Menteri Kelautan dan Perikanan sebagai komoditas alternatif dengan maksud untuk membangkitkan kembali usaha pertambakan udang selama budidaya udang windu masih banyak menemui kendala. Udang vanamei ini cukup potensial untuk dikembangkan di Sulawesi Selatan, bukan saja pembudidaya bermodal besar tetapi pembudidaya bermodal kecilpun dapat mengembangkannya. Namun banyak tantangan yang harus dihadapi, terutama yang menyangkut masih lambatnya dan belum sepenuhnya dikuasai oleh sumber daya manusia perikanan bahkan masih adanya anggapan bahwa udang vanamei hanya dapat dibudidayakan secara intensif. Di lain pihak belum terwujudnya pembinaan kelembagaan kelompok pembudidaya yang profesional, tangguh, dan memiliki visi ke depan dan dukungan permodalan yang masih minim.
\end{abstract}

KATA KUNCl: udang vanamei, potensi, kendala, Sulawesi Selatan

\section{PENDAHULUAN}

Produktivitas budidaya udang terutama udang windu di Indonesia mencapai puncaknya pada tahun 1991--1994. Setelah periode tersebut produksi udang budidaya semakin menurun. Hal ini karena terjadinya kegagalan panen sebagai akibat penurunan kualitas lingkungan, kesalahan dalam penerapan teknologi dan merebaknya bermacam-macam penyakit. Di sisi lain, jumlah kebutuhan konsumsi masyarakat internasional semakin meningkat. Keterbatasan jumlah pasokan dan peningkatan jumlah kebutuhan menyebabkan harga udang semakin naik. Kondisi ini merupakan peluang yang sangat baik bagi suatu daerah penghasil udang, seperti Sulawesi Selatan untuk dapat meningkatkan jumlah produksi udangnya. Untuk mencapai sasaran tersebut, oleh pemerintah ditetapkan beberapa langkah operasional yang kongkrit di antaranya adalah pengembangan udang vanamei di samping udang windu, rostris, dan udang lokal lainnya (Tonnek et al., 2005).

Udang vanamei ternyata tidak saja menghasilkan produksi yang tinggi tetapi juga mampu membangkitkan kembali usaha pertambakan nasional yang tadinya sudah mulai lesu (Anonim, 2003). Perkembangan udang vanamei sudah menyebar di sentra-sentra budidaya udang nasional seperti di Jawa Timur, Jawa Barat, Jawa Tengah, Lampung, Kalimantan Barat, Kalimantan Timur, Nusa Tenggara Barat, Bali, dan Sulawesi Selatan (Poernomo, 2002; Sugama, 2002). Umumnya usaha budidaya udang vanamei tersebut masih dimonopoli petambak intensif (kepadatan tinggi) yang bermodal besar.

Udang vanamei (Gambar 1) termasuk ordo Decapoda, seperti halnya dengan udang windu, namun udang vanamei termasuk tipe pemakan lambat tetapi terus-menerus (continous feeder) dan menyukai hidup di dasar dan semua kolam air (Haliman \& Adijaya, 2005).

Sejak diperkenalkannya udang vanamei, Litopenaeus vannamei di Sulawesi Selatan baru beberapa kabupaten saja yang mengusahakan budidaya udang sebagai salah satu komoditas alternatif di tambak, dan menunjukkan peningkatan produksi yang signifikan. Namun demikian, peningkatan produksi ini belum sepenuhnya mencerminkan perbaikan usaha pertambakan udang, karena peningkatan produksi tersebut umumnya

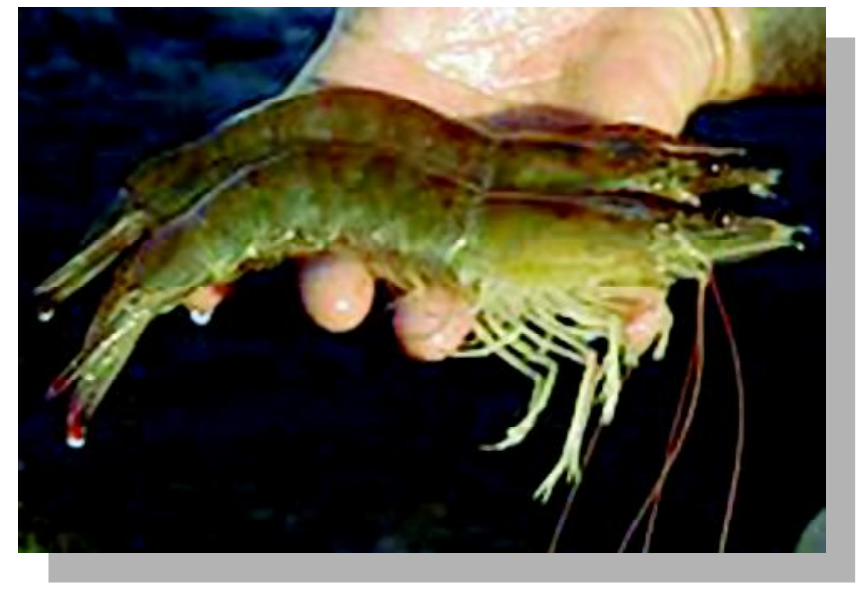

Gambar 1. Udang vanamei (Litopenaeus vannamei) 
masih berasal dari udang vanamei yang diproduksi oleh perusahaan-perusahaan yang bermodal besar. Berbeda dengan zaman kejayaan udang windu, di mana produksi yang besar dihasilkan oleh petambak tradisional secara semi-intensif yang jumlahnya saat ini mencapai $80 \% \mathrm{Hal}$ ini merupakan tantangan dan sekaligus peluang bagi daerah Sulawesi Selatan untuk menciptakan peluang pasar, baik untuk memenuhi kebutuhan di dalam negeri maupun ekspor.

\section{Potensi Produksi}

Sulawesi Selatan (Gambar 2) dengan panjang garis pantai mencapai $2.500 \mathrm{~km}$ dengan luas tambak 105.663 ha (Anonim, 2004). Luas tambak yang sudah berproduksi yang ada saat ini (existing) maupun potensial serta pemanfaatannya masing-masing kabupaten dapat dilihat pada Tabel 1.

Sampai akhir tahun 2005 tambak yang ada dan sudah berproduksi saat ini sudah mencapai 52.540 ha atau sekitar 35,61\%dari potensi lahan yang 96.002 ha (Tabel 1), berarti masih dibutuhkan sekitar 7.000 ha lahan potensial yang secara bertahap, akan terpenuhi hingga

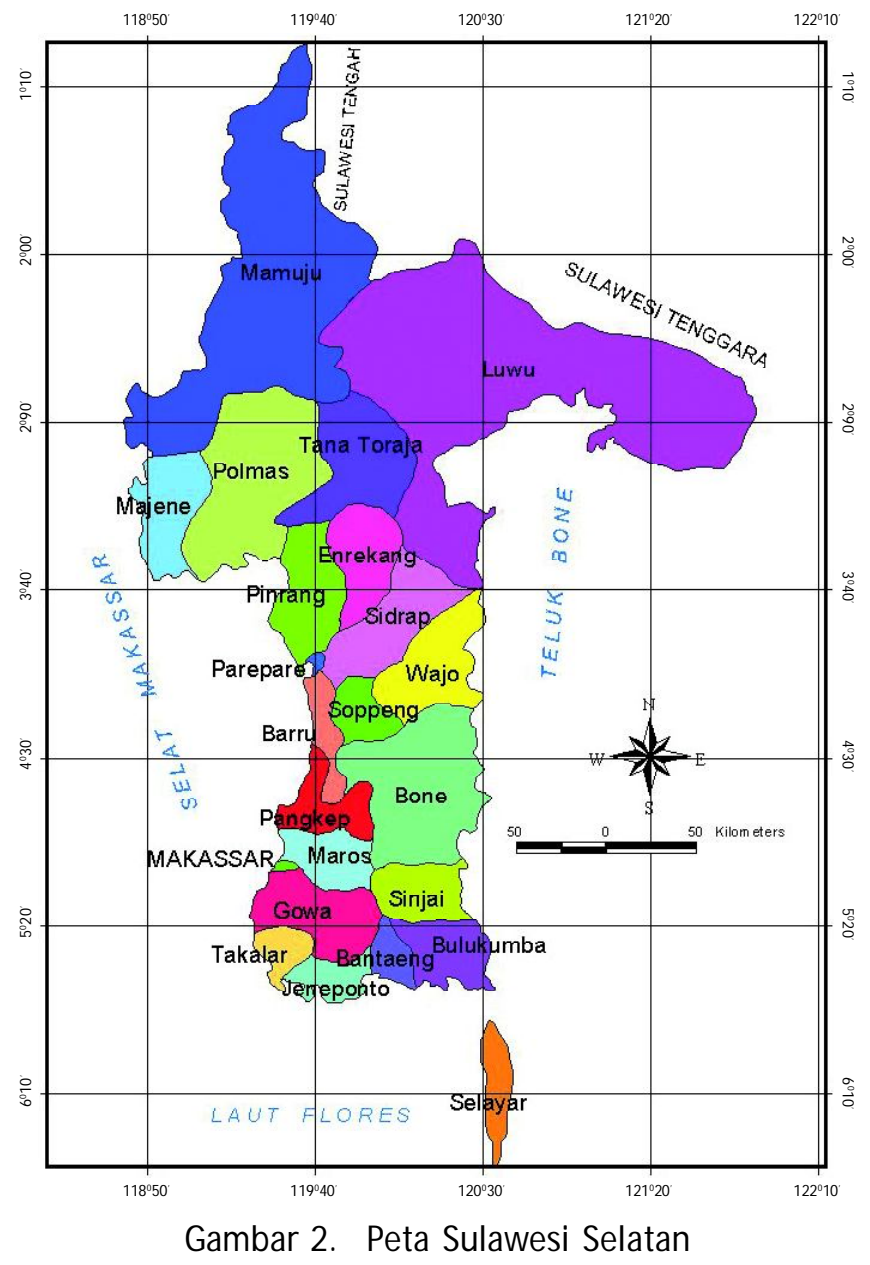

Tabel 1. Luas lahan tambak eksisting dan potensi untuk budi daya udang di Sulawesi Selatan tahun 2005

\begin{tabular}{|c|c|c|c|}
\hline \multirow{2}{*}{$\begin{array}{c}\text { Kabupaten/ } \\
\text { Kota }\end{array}$} & \multicolumn{2}{|c|}{ Luas Iahan (ha) } & \multirow{2}{*}{$\begin{array}{c}\text { Tingkat } \\
\text { Pemanfaatan } \\
(\%)\end{array}$} \\
\hline & Potensi & Eksisting & \\
\hline Luwu & 4.408 & 3.710 & 45,71 \\
\hline W ajo & 12.988 & 10.924 & 45,45 \\
\hline Bone & 10.810 & 8.945 & 47,91 \\
\hline Sinjai & 678 & 462 & 40,4 \\
\hline Bulukkumba & 3.763 & 2.576 & 41,73 \\
\hline Selayar & 858 & 624 & 42,1 \\
\hline Bantaeng & 191 & 170 & 47,9 \\
\hline Jeneponto & 2.652 & 1.471 & 35,23 \\
\hline Takalar & 4.100 & 4.000 & 49,38 \\
\hline Makassar & 1.180 & 1.020 & 48,57 \\
\hline Maros & 9.386 & 8.501 & 47,52 \\
\hline Pangkep & 12.527 & 11.367 & 49,67 \\
\hline Barru & 2.399 & 2.009 & 49,88 \\
\hline Pare-Pare & 68 & 42 & 38,18 \\
\hline Pinrang & 15.853 & 13.735 & 49,81 \\
\hline Gowa & 156 & 118 & 45,07 \\
\hline Luwu Utara & 7.628 & 5.147 & 44,62 \\
\hline Luwu Timur & 5.441 & 4.223 & 49,06 \\
\hline Palopo & 916 & 785 & 49,13 \\
\hline Jumlah & 96.002 & 52.540 & 35,61 \\
\hline
\end{tabular}

Sumber: Anonim (2006)

tahun 2009, dengan pertambahan 9\%-11\%tahun. Volume ekspor udang daerah Sulawesi Selatan cenderung turun akibat gagal panen terutama disebabkan penyakit virus bintik putih, white spot syndrom virus (WSSV) dan bakteri V. Harveyi yang mengakibatkan kerugian dengan prediksi sekitar 33,4 juta USD/tahun. Proyeksi udang baik udang windu, vanamei dan udang lainnya di Sulawesi Selatan dari tahun 2005--2009 dapat dilihat pada Tabel 2.

Ketersediaan sumber daya lahan untuk budidaya di tambak, iklim yang mendukung dan sumber tenaga kerja yang trampil, daerah Sulawesi Selatan sangat ideal dan potensial untuk dikembangkan budidaya udang vanamei.

Udang vanamei merupakan jenis udang yang akhirakhir ini banyak diminati karena memiliki keunggulan seperti relatif tahan penyakit, pertumbuhan cepat (masa pemeliharaan 100--110 hari), sintasan tinggi dan konversi pakan (FCR) yang rendah.

Informasi tentang padat penebaran udang vanamei di tambak telah banyak dilaporkan antara lain di Panama, padat tebar 20--30 ind./ $\mathrm{m}^{2}$ yang digunakan dalam budidaya di tambak mampu memproduksi 1,9--2,9 ton/ha/91 hari pemeliharaan (Athanasiadis \& Chaves, 2002 dalam Sugama, 2002) sedangkan di Ecuador dengan padat tebar 
Potensi dan kendala pengembangan budi daya udang vanamei di Sulawesi Selatan (Abdul Mansyur)

Tabel 2. Proyeksi produksi udang Sulawesi Selatan

\begin{tabular}{lccccc}
\hline \multirow{2}{*}{ Komoditi (ton) } & \multicolumn{5}{c}{ Tahun } \\
\cline { 2 - 6 } & $\mathbf{2 0 0 5}$ & $\mathbf{2 0 0 6}$ & $\mathbf{2 0 0 7}$ & $\mathbf{2 0 0 8}$ & $\mathbf{2 0 0 9}$ \\
\hline Udang windu & 15.000 & 15.750 & 16.540 & 17.400 & 18.300 \\
Udang vanamei & 12.000 & 20.000 & 30.000 & 40.000 & 60.000 \\
Udang lainnya & 2.000 & 2.000 & 2.000 & 2.000 & 2.000 \\
\hline \multicolumn{1}{c}{ Total proyeksi } & $\mathbf{2 9 . 0 0 0}$ & $\mathbf{3 7 . 7 5 0}$ & $\mathbf{4 8 . 5 4 0}$ & $\mathbf{5 9 . 4 0 0}$ & $\mathbf{8 0 . 3 0 0}$ \\
\hline
\end{tabular}

Sumber: Anonim (2005)

75--120 ekor/m² mampu memproduksi 4,9--5,8 ton/ha/ siklus (Salame \& Salame, 2002 dalam Sugama, 2002). Di Indonesia padat tebar udang vanamei yang umum dilakukan di berbagai daerah berkisar $80--100$ ind. $/ \mathrm{m}^{2}$ udang vanamei dan dapat ditingkatkan hingga 244 ind./ $\mathrm{m}^{2}$, bila menggunakan probiotik mampu menghasilkan 37,5 ton/ha/siklus.

Penelitian pembesaran udang vanamei dengan kepadatan rendah secara tradisional plus di Maros, Sulawesi Selatan telah dirintis oleh Balai Riset Perikanan Budidaya Air Payau sejak tahun 2005, tetapi masih terbatas pada komponen teknologi aspek padat penebaran yang mana menurut Hendrajat \& Mangampa (2005), bahwa padat tebar 8 ekor $/ \mathrm{m}^{2}$ memberikan hasil yang terbaik dengan bobot rata-rata, sintasan, produksi, dan rasio konversi pakan masing-masing 14,37 g/ekor; 60,97\% 70,09 $\mathrm{kg} / 900 \mathrm{~m}^{2}$ dan 1,79 .

\section{Kendala yang Dihadapi}

Pengembangan budidaya udang vanamei di daerah Sulawesi Selatan menghadapi beberapa kendala, antara lain alih teknologi budidaya yang relatif masih lambat dan belum sepenuhnya dikuasai oleh pelaku/pembudidaya perikanan misalnya adanya anggapan bahwa udang vanamei hanya dapat dibudidayakan secara intensif. Anggapan tersebut ternyata tidaklah sepenuhnya benar, karena hasil kajian menunjukkan bahwa udang vanamei dapat juga diproduksi dengan pola tradisional (kepadatan rendah). Bahkan dengan pola tradisional petambak dapat menghasilkan ukuran panen yang lebih besar dengan nilai jual yang lebih besar. Namun informasi aplikasi pola tradisional (kepadatan rendah) sampai saat ini masih sangat terbatas, sehingga penyempurnaan dan perbaikan terhadap aspek teknologinya masih diperlukan.

Aspek lain adalah belum terwujudnya pembinaan kelembagaan kelompok pembudidaya yang profesional, tangguh dan memiliki visi ke depan serta dukungan permodalan yang masih minim.
Pemasaran produk udang vanamei tidak mengalami hambatan, karena selama ini produk udang vanamei selalu dapat terjual baik memenuhi kebutuhan masyarakat lokal maupun untuk pemasaran ekspor. Berdasarkan kenyataan ini maka panti benih yang ada di Sulawesi Selatan perlu mempertahankan benih yang bebas virus. Setiap benih yang akan dilepas ke pasaran sebaiknya mendapat rekomendasi bebas pathogen, Spesifik Pathogen Free (SPF) disertai jaminan kualitas dari pihak perbenihan (hatchery) sebelum penebaran.

\section{Pengembangan Budidaya Udang Vanamei}

\section{Peranan udang vanamei}

Dewasa ini, di daerah Sulawesi Selatan budidaya udang vanamei yang diusahakan secara intensif (kepadatan tinggi) tidak hanya ditemui di Bulukumba, namun sudah menyebar ke berbagai kabupaten seperti Bantaeng, Barru, dan Takalar (Gambar 2). Budidaya udang vanamei saat ini masih dimonopoli petambak intensif yang bermodal besar, namun beberapa daerah seperti Pinrang, Selayar, dan Maros sudah melaksanakan budidaya padat penebaran rendah (tradisional plus) maupun semi-intensif. Di daerah tersebut budidaya vanamei cukup berhasil dan diharapkan akan diikuti oleh petambak di sekitarnya seperti Pangkajene Kepulauan (Pangkep), Sinjai, Bone, Luwu, dan sebagainya.

Berdasarkan pengamatan di Kabupaten Maros (Sulawesi Selatan) bahwa dengan kepadatan rendah (8 ekor $/ \mathrm{m}^{2}$ ) berperan penting dalam menunjang pendapatan keluarga. Dengan usaha budidaya kepadatan rendah, panen udang vanamei mencapai 700--835 kg/ha/musim tanam dengan sintasan 60\%-70\% ukuran panen antara 55-65 ekor/kg dengan masa pemeliharaan 105 hari dengan keuntungan per musim tanam sebesar Rp 8.225.500,-. Dengan keuntungan yang sangat memadai maka usaha budidaya udang vanamei kepadatan rendah dapat menunjang perekonomian pedesaan dan menciptakan kesempatan kerja (Hendrajat \& Mangampa, 2005). 


\section{Dukungan yang diperlukan}

Untuk mewujudkan iklim usaha yang kondusif bagi pengembangan udang vanamei di daerah Sulawesi Selatan diperlukan dukungan dari stake holders yang terkait antara lain: 1) pemerintah daerah dalam hal ini Gubernur dan Bupati sebagai pembina di lapangan sangat diperlukan dukungannya yang berperan penting baik dalam komando serta pembinaan seperti Dinas Perikanan dan Kelautan diharapkan bisa menjadi motor penggerak dan sebagai pelaksana di lapangan, 2) penyuluhan dan pelatihan serta tenaga pendampingan yang merupakan jembatan untuk sampainya teknologi kepada pengguna/pembudidaya dan 3) Unit Pelaksana Teknis seperti Balai Budidaya Air Payau di Takalar dan Balai Riset Perikanan Budidaya Air Payau yang ada di Maros, Sulawesi Selatan diharapkan menjadi Pusat Informasi Teknologi Budidaya bagi masyarakat khususnya pembudidaya.

\section{KESIMPULAN}

Melihat prospeknya yang cukup cerah, sebenarnya udang vanamei jika dikelola dengan persiapan tambak, penebaran, pemeliharaan sampai panen yang terencana dengan tingkat pengusahaannya yang baik tidak mustahil usaha tersebut dapat dikembangkan sebagai usaha utama. Namun prospek dan harapan tersebut hanya dapat terwujud jika segala kendala dapat diatasi dengan baik dan adanya dukungan semua pihak seperti pemerintah daerah, penyuluh dan Unit Pelaksana Teknis yang ada di Sulawesi Selatan.

\section{DAFTAR PUSTAKA}

Anonim. 2003. Usaha pertambakan udang vanamei prosfektif. Forek@ forek.or.id. 23 April 2003.5 pp.

Anonim. 2004. Implementasi kebijakan pembangunan sektor kelautan dan perikanan di Sulawesi Selatan. Dinas Perikanan dan Kelautan Propinsi Sulawesi Selatan, Makassar. 11 pp.

Anonim. 2006. Statistik Perikanan. Dinas Perikanan dan Kelautan Sulawesi Selatan. Makassar. 282 pp.

Anonim. 2005. Laporan Tahunan Perikanan dan Kelautan Sulawesi Selatan. Makassar. 94 pp.

Haliman, R.W. dan D. Adijaya S. 2005. Udang Vannamei, Pembudidayaan dan Prospek Pasar Udang Putih yang Tahan Penyakit. Penebar Swadaya. Jakarta. 75 pp.

Hendrajat, E.A. dan M. Mangampa. 2005. Revitalisasi bekas tambak udang yang terlantar menjadi tambak udang vannamei (Litopenaeus vannamei) tradisional plus, Laporan Hasil Penelitian. Balai Riset Perikanan Budidaya Air Payau, Maros. 10 pp.

Poernomo, A. 2002. Perkembangan udang putih vannamei (Penaeus vannamei ) di Jawa Timur. Disampaikan dalam Temu Bisnis Udang. Makassar, 19 Oktober 2002. 26 pp.

Sugama, K. 2002. Status budidaya udang introduksi Litopenaeus vannamei dan Litopenaeus stylirostris serta prospek pengembangannya dalam tambak air tawar. Disampaikan dalam Temu Bisnis Udang. Makassar, 19 Oktober 2002. 7 pp.

Tonnek, S., M. Mangampa, E.A. Hendrajat, dan H.S. Suwoyo. 2005. Kesiapan teknis dalam mendukung revitalisasi perikanan dan kelautan Sulawesi Selatan. Makalah disampaikan dalam Pertemuan Teknis Petugas Inbud se Sul-Sel di Makassar, 26 Oktober 2005. 10 pp. 